\title{
PREKMURJE KOT NERAZVITO OBMEJNO OBMOČJE V SLOVENIJI
}

\author{
Vladimir Klemenčic *
}

IZVLEČEK

UDK 911.3(497.12-18-04)

V razpravi so obravnavani procesi razkroja statiðne agrarne in oblikovanje prostorske strukture urbane družbe ter diferenciacija na periferna in centralna območja na primeru Prekmurja, $\mathrm{z}$ uðinki zaprte slovensko-madžarske in odprte slovensko-avstrijske meje.

ABSTRACT

UDC 911.3(497.12-18-04)

THE PREKMURJE - AN UNDERDEVELOPED FRONTIER AREA OF SLOVENIA

The paper deals with the following processes: disintegration of spatial structure of agrarian society and formation of spatial structure of urban society; spatial differentiation into periphereal and central areas; and the impacts of the unopenness of the Slovenian-Hungarian border, as well as the openness of the Slovenian-Austrian border.

\section{UVOD}

Prekmurje predstavlja tipičen primer obmejne regije,kamor so sele v zadnjih treh desetletjih segle intenzivnejše oblike industrializacije in s tem $\mathbf{v}$ zvezi so se oblikovali močnejši centri neagrarne zaposlitve. Zato tudi urbanizacija ni zajela Siršega podeželja. Zaradi obmejne lege in s tem povezanimi problemi, ob državnih mejah z Avstrijo in Madžarsko, se je Premurje po tendencah socialne in gospodarske preobrazbe prostorsko zdiferenciralo na tri obmoxja:

- obmox́je praznenja prebivalstva $\mathrm{z}$ razkrojem kulturne pokrajine,

- obmoxje koncentracije prebivalstva s procesi preobrazbe iz agrarnega $\mathrm{v}$ neagrarni tip podeželja in

- prehodna obmoxja (Klemencix, 1971).

Obmox̌je praznenja prebivalstva se se nadalje deli: na najintenzivnejふ̌a obmoxja praznenja ob madžarski meji in na relativno manj izrazita obmoxja praznenja, ki so se zaradi štiridesetletne različne stopnje odprtosti avstrijske meje izoblikovala v glavnem v zahodnem delu Prekmurja.

Obmoxja koncentracije se dalje delijo na tista obmox̌ja starejక̌e urbanizacije, katere zametki segajo $\mathrm{v}$ petdeseta leta in na obmoxja mlajše urbanizacije iz sedemdesetih let.

Ta notranja členitev,ki jo je mogoče utemeljevati z mikrogeografskimi analizami pa je na eni strani pogojena s historǐnim družbeno-geografskim razvojem in na drugi strani s fizix̌no-geografskimi danostmi Prekmurja, ki se deli na ravninski svet na levi strani Mure in na griðevnato

\footnotetext{
* Dr, red. univ. prof, Oddelek za geografijo, Filozofska fakulteta, Aškeř̌eva 12, 61000 Ljubljana, Slovenija
} 
Goriðko, katerega velik del je po prvi svetovni vojni postal ožje obmejno obmoð̌je.Sedanji razvoj pa je tudi posledica obrobnega politǐ̌no-geografskega položaja med jugoslovansko-avstrijsko in jugoslovansko-madžarsko državno mejo. Prav ta obrobnost, ki jo కe posebej poudarja relativna zaostalost obmejnih obmoxij na avstrijski in madžarski strani, pa je eden od glavnih vzrokov zaostajanja Prekmurja za ostalimi obmoxji Republike Slovenije.

\section{GEOGRAFSKE DANOSTI PREKMURJA IN NJIHOVA IZKORIŠČENOST}

V fiziðno-geografskem pogledu predstavlja Prekmurje prehodno območje med alpskim in panonskim svetom. Ta prehodnost je utemeljena tudi $\mathrm{z}$ oblikovanjem političnih meja, kar je bilo $\mathrm{v}$ razliěnih zgodovinskih obdobjih izraženo tudi $\mathrm{v}$ kulturno-geografskem razvoju podobe in funkcije pokrajine. Politǐ̌ne meje so se na tem ozemlju oblikovale že od XII. stoletja dalje. Tako je bila današnja politǐ̌na meja med Prekmurjem v Sloveniji in južnim Gradišcanskim ter Štajersko v Avstriji začrtana že v XII. stoletju, ko je se ločevala avstrijski in ogrski del Avstro-Ogrske. Nespremenjena je ostala do konca prve svetovne vojne. Spremenila se niti po prvi svetovni vojni, ko je med obema vojnama locevala tedanjo Avstrijo in Kraljevino Srbov, Hrvatov in Slovencev, niti po drugi svetovni vojni. Medtem, ko je meja z Avstrijo nespremenjena že več stoletij, pa se je današnja jugoslovansko-madžarska meja izoblikovala šele po letu 1924. Najprej je ločevala Madžarsko od Kraljevine Srbov, Hrvatov in Slovencev, po drugi svetovni vojni pa ločuje Prekmurje od županij Vas in Zala na Madžarskem.

Naravni značaj Prekmurja, med panonskim in alpskim svetom ter spreminjanje meja, ki so vključcvale Prekmurje v različne državne tvorbe s specifičnimi družbeno-gospodarskimi in politǐ̌nimi sistemi, je kljub podobnim geografskim danostim, zlasti za kmetijstvo, prispeval $\mathbf{k}$ drugacnemu razvoju kulturne pokrajine in funkcije Prekmurja, kot ga sledimo v sosednjih, podobnih obmoxjjih na Madžarskem ter na južnem Gradišcanskem in Štajerskem v Avstriji.

Prehodnost tega subpanonskega ozemlja je prišla močno do izraza $\mathbf{v}$ casu najglobljega vdora Turkov v Srednjo Evropo (XVI/XVII. stol.), ko je Prekmurje predstavljalo mejni pas med Tur夭̌ijo in tedanjo Avstrijo. Ker ni bilo varovano z Vojno krajino,kot ostala mejna obmoðja med Turcijo in Avstrijo, je doživelo stevilne turške vpade. Zato se je prebivalstvo selilo $\mathbf{v}$ gricevnat, za kmetijstvo sicer manj primeren goricki svet. To je povzroxilo visoko agrarno prenaseljenost Goričkega, katere zlasti na najbolj obrobnih obmejnih obmoxjih ni bilo mogoce premagati vse do danes.

Pri posebnostih razvoja Prekmurja, ki je bilo že v Avstro- Ogrski Monarhiji obmejno območje Ogrske, moramo se posebej podrrtati dedno pravo. To je,za razliko od avstrijskega dela Monarhije,pogojevalo delitev kmetij med dedice, kar je že po prvi svetovni vojni pripeljalo do tako razdrobljene zemljisko posestne sestave,da se velika veそ̌ina družin ni mogla preživljati. Ta posestna razdrobljenost je vse do noveǰ̌ega razdobja silila prekmursko prebivalstvo $\mathrm{k}$ iskanju svoje eksistence z razlǐnimi oblikami selitev (Olas, 1990). Do prve svetovne vojne se 
je prebivalstvo selilo le na sezonska kmečka dela znotraj Ogrske, v obdobju med obema vojnama pa se pojavijo tudi selitve na sezonska nekmecka dela. Šele po drugi svetovni vojni selitve na sezonska nekmeð̌ka dela dokončno prevladajo in prebivalstvo se zacne seliti predvsem v Zahodno Evropo. Medtem, ko se je do konca prve svetovne vojne odseljena delovna sila vracala po nekajmesečni sezonski zaposlitvi nazaj $v$ Prekmurje $\mathrm{k}$ svojim družinam, pa velik del odseljenih po drugi svetovni vojni v Zashodno Evropo, ostaja tam vsaj nekaj let in se sele nato vrne za stalno domov, veliko pa se jih kot izseljenci za stalno naseli v Zahodni Evropi (Olas, 1956). Prebivalstvo Prekmurja se je od konca prejšnjega stoletja vkljucevalo tudi v selitve evropskega prebivalstva na druge kontinente, najprej v Združene države Amerike, med obema vojnama v Argentino, po drugi svetovni vojni pa v Kanado in Avstralijo (Olas, 1960).

Pred začetkom industrializacije je vse do šstdesetih let hodilo iz Prekmurja na razna sezonska dela med 12.000 in 14.000 ljudi, s pricetkom industrializacije in upadanjem naravne rasti prebivalstva v sedemdesetih letih pa naj bi bilo na sezonskem delu se okrog 4.000 ljudi. To so v tujini zaposleni prebivalci Prekmurja, ki imajo doma svojo družino ali pa vzdržujejo intenzivne stike s svojimi starši. Večja zaposlitvena jedra teh sezonskih delavcev najdemo na avstrijskem Štajerskem ter v južni Nem̌iji, zlasti v okolici Ingolstadta (Olas,1978).

Zelo pomembna v kulturno-geografskem razvoju Prekmurja od konca prejకnjega stoletja je bila razmejitev med Prekmurjem in Štajersko ter južnim Gradišanskim v Avstriji. Industrializacija Štajerske je vse do druge svetovne vojne povzroæala izseljevanje malih kmetov s svojimi družinami v gospodarsko razvijajoče se predele Štajerske in ostale Avstrije. Kmetije, ki so jih ti odseljenci prodajali predvsem na Apaški ravnini, Murskem polju ter na obmoxju Radgone, pa so $\mathrm{z}$ denarjem, zasluženim v izseljeništvu (Amerika) kupovali Prekmurci (Olas, 1963). Razlike v gospodarskem razvoju obmejnih obmoxij v Prekmurju in na Štajerskem ter na južnem Gradišcanskem v Avstriji so se po drugi svetovni vojni క̌ povečale.Zaradi izseljevanja avstrijskega prebivalstva iz obmejnih obmoxij vzhodne Štajerske in južnega Gradišcanskega v notranjost Avstrije, je tukaj v primerjavi z ostalo Avstrijo prišlo do relativnega gospodarskega zaostajanja in do pomanjkanja delovne sile $v$ kmetijstvu. Kerr tega ni nadomestila modernizacija tehnologije v v kmetijstvu, je sem prihajala delovna sila iz Prekmurja kar traja deloma se danes. To je $\mathbf{v}$ veliki meri omililo gosdpodarsko in socialno stisko obmejnega prebivalstva $\mathbf{v}$ Prekmurju, ki mu je razdrobljena posest do tedaj bila edini vir dohodka. Povprečna velikost kmetij je bila okrog 4 hektarjev, okrog 20 ali manj arov nekaj kilometrov oddaljenih in razmetanih parcel po vsem vaškem zemljišcu. Te majhne kmetije so lahko imele tudi po 15 in ve夭 takih parcel (Olas, 1972).

Že ta prednost, ki so imeli prebivalci Prekmurja ob avstrijski meji pred prebivalci, ki so živeli ob zaprti madžarski meji, je postala nova pozitivna inovacija družbeno-ekonomske preobrazbe obmejnih obmoxij. K oblikovanju obmejnega obmoxja, ki je pod vplivom odprte avstrijske meje kazalo relativno izboljšanje socialnega položaja prebivalstva v Prekmurju, je prispevalo tudi veCanje stevila mejnih prehodov in tehniðno opremljanje le-teh. Tako je do leta 1990 bilo 
na 28 kilometrih slovensko-avstrijske meje v Prekmurju 8 mejnih prehodov, od katerih sta dva mednarodnega pomena. Tudi število potnikov, ki preðka mejo na tem območju se iz leta $\mathrm{v}$ leto povecuje. Tako se je stevilo potnikov povecalo iz 1,2 milijona leta 1981 na 1,6 milijona leta 1988. Mednarodna mejna prehoda $v$ Gederovcih in Kuzmi pa nista pomembna le za prehajanje prebivalstva obmejnih obmoxij iz ene strani meje na drugo stran, temvec vse bolj pridobivata tudi funkcijo mednarodne tranzitne poti delavcev, ki so na začasnem delu v Zahodni Evropi, predvsem v Južni Nemčiji in Avstriji. Njuna prometno tranzitna vloga je కe posebej poudarjena ob koncu tedna ter $\mathrm{v}$ casu letnih in zimskih dopustov, to je $\mathrm{v}$ obdobju turistißnih selitvenih tokov med Evropo ter Jugoslavijo, Grčijo in Turčijo.

Povezovanje prebivalstva ožjega obmejnega pasu s krajsimi sezonskimi deli na Štajerskem in južnem Gradišcanskem ali pa v obliki dnevnega potovanja na delo preko meje ter migracijski tokovi delavcev ob koncu tedna, sezonsko ali preko celega leta, je $\mathbf{v}$ veliki meri prispevalo $\mathbf{k}$ večji poselitveni stabilnosti prebivalstva ob avstrijski meji, kakor pa lahko to sledimo ob zaprti madžarski meji, kjer je velik del obmejnega obmoxja postal izrazito depopulacijsko in poselitveno labilno obmoxje.

Pri oblikovanju mejne crte med Madžarsko in Kraljevino Srbov, Hrvatov in Slovencev leta 1924 so bile pretrgane vse železniške in cestne povezave med Monoštrom in Mursko Soboto ter Lendavo in Lentyem. Del kmetijskih zemljišx vasi, ki so pripadla Jugoslaviji je ostal na obmejnih območjih sosednje Madžarske, obratno pa so deli zemljišc, ki so pripadli madžarskim vasem ostali na jugoslovanski strani (Sožitje...,1987). Pri oblikovanju meje tudi niso bile upoštevane meje కolskih okolišev in fara, pa tudi del gravitacijskega zaledja centralnega kraja Lendave je ostal na Madžarskem. Medtem, ko so mejni prehodi na madžarsko-jugoslovanski meji do leta 1948 se povezovali skoraj vse obmejne kraje, pa je prišlo po tem letu do skoraj povsem hermetixne zaprtosti meje. Skromnejše oblike osebnega in blagovnega mednarodnega prometa se začnejo znova pojavljati sele v sestdesetih letih, nekaj intenzivnejß̌e pa sele v osemdesetih letih, pa se to le na dveh mejnih prehodih (Hodoš, Dolga vas).

Medtem, ko vse do sedemdesetih let o prekomejnem povezovanju obmejnih območij z obeh strani madžarske meje skoraj ne moremo govoriti in ko skromen prekomejni promet poteka preko madžarske meje, ki meri v Prekmurju 88 kilometrov le preko dveh mejnih prehodov (Dolga vas, Hodoš), so kraji Prekmurja ob avstrijski meji intenzivno povezani z obmejnimi kraji onstran meje v Avstriji že od leta 1960 dalje. Takrat sta namrex Avstrija in Jugoslavija podpisali najprej dogovor o možnosti izkorišcanja dvolastniške zemlje kmetov iz Prekmurja ter kmetov iz Štajerske in južnega Gradišcanskega (Olas, 1976; Karta 1), nekaj pozneje pa so podpisali tudi dogovor o maloobmejnem prometu, kar predvsem $v$ novejšem razdobju predstavlja pomembno osnovo za regionalno povezovanje prebivalstva $\mathrm{z}$ obeh strani meje. $\mathrm{Z}$ ukinitvijo viz za prestopanje meje pa sta postali na podlagi obojestranskih prehodov preko meje v zvezi z vsakodnevnimi nakupi in s turistixnimi obiski zdraviliških krajev Prekmurja ter skupaj $\mathrm{z}$ zaposlovanjem prekmurskega prebivalstva $\mathbf{v}$ Avstriji obmejni območji $\mathrm{z}$ obeh strani 
Tabela 1

Število potnikov in blaga (v tonah) na jugoslovansko-avstrijski in jugosłovansko-madžarski meji leta 1981 in 1988

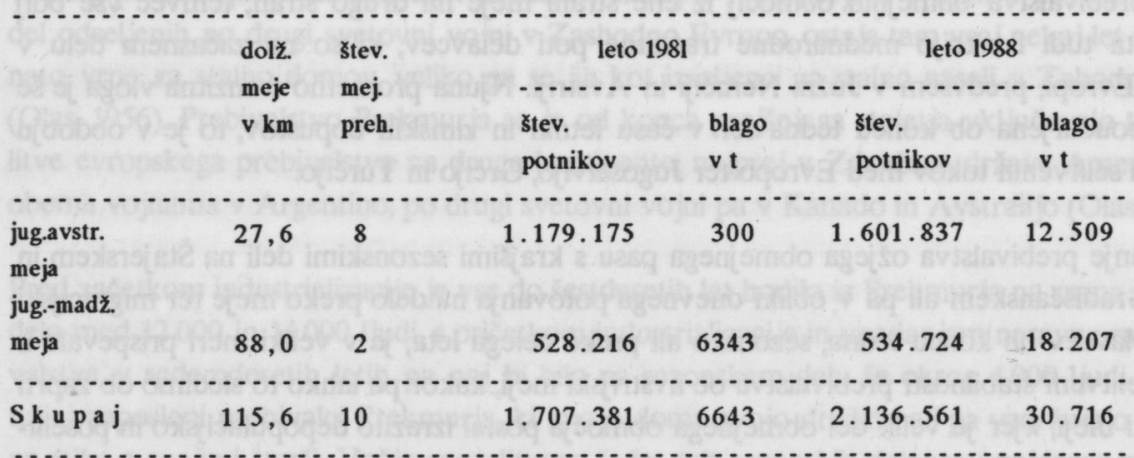

slovensko-avstrijske meje gospodarsko bolj ali manj soodvisni in med seboj povezani, tako, da sta se v nove jక̌em Casu preoblikovali v pravo obmejno regijo.

Na drugi strani pa so obmejni kraji ob jugoslovansko-madžarski meji se naprej povezani z obmejnimi kraji sosednje Madžarske le preko dveh mejnih prehodov. Tudi prehajanje dvolastnikov preko meje, ki je bilo pred drugo svetovno vojno se zelo živahno, je zaradi podružabljanja zemlje lastnikov iz Slovenije na madžarski strani povsem zamrlo. Vse to je v Prekmurju కe bolj zmanjふalo velikost kmetij in కe poslabక̌alo socialni položaj prebivalstva.

Po drugi svetovni vojni je Prekmurje vse do sedemdesetih let ostalo skoraj izven procesa industrializacije in urbanizacije tedaj še močno agrarno prenaseljenega podeželja, ki je takrat v večji ali manjł̌ meri zajel že skoraj vsa obmoxja Slovenije. Šele v zadnjih tridesetih letih je s policentričnim razvojem Slovenije, ki je slonel na osnovi Zakona o pospeševanju gospodarskega razvoja manj razvitih obmoxij Slovenije iz leta 1971, postopna industrializacija zajela tudi Prekmurje. Tako so bila na podlagi tega zakona deležna gospodarskega pospeševanja vsa tista obmoxja, kjer je bil narodni dohodek nižji kot 5.000 din na prebivalca in ki so imela leta 1971 več kot $40 \%$ kmečkega prebivalstva ter manj kot $20 \%$ aktivnega prebivalstva zaposlenega izven kmetijstva. Po tem Zakonu naj bi bilo hitre jšega gospodarskega razvoja deležno celotno Prekmurje, vendar pa so kljub temu ostala obsežna hribovska, se zlasti pa obmejna obmoxja Gorickkega §e naprej nerazvita. Zato so ob koncu leta 1990 sprejeli se Zakon o spodbujanju razvoja demografsko ogroženih obmoxij, ki se nanaša na vse tiste krajevne skupnosti, kjer rast prebivalstva leta 1981 ne presega $25 \%$ povprečne rasti prebivalstva v Republiki Slo- 
veniji in ki imajo indeks staranja za najmanj 25 indeksnih tock manj ugoden, kakor znaša povprecje za Republiko Slovenijo. Po tem Zakonu, ki daje v razvoju prednost obmejnim in narodnostno meSanim obmoxjem, pa je v spodbujanje razvoja vkljucen celoten hribovit svet Goriðkega, saj se na vexini teh obmoxij kažejo tendence razkroja demografske strukture prebivalstva. Na osnovi Zakona iz leta 1971 lahko sledimo ob ve`anju కtevila in disperziji కtevila krajev $\mathrm{z}$ industrijo tudi hitri rasti Stevila prebivalstva, zaposlenega $\mathrm{v}$ sekundarnem sektorju in oblikovanju gravitacijskih zaledij dnevne migracije delovne sile.

Medtem, ko je bilo $\mathbf{v}$ Prekmurju pred sprejemom Zakona o gospodarskem pospeševanju nerazvitih obmoxij le nekaj krajev $\mathrm{z}$ industrijo, ki so bili $\mathrm{v}$ glavnem le na ravninskem svetu, pa so do leta 1990 nastali kraji $z$ industrijo na celotnem ozemlju Prekmurja. Na ožjem obmejnem obmoxju so kraji z industrijo nastali le ob madžarski meji na obmox̌ju Lendave, ki že dobiva značaj mlade industrijske regije, ob avstrijski meji pa razen nekaj manjsih industrijskih obratov kraji niso dobili pomembnejse industrije (Karta 2). Novi industrijski kraji, ki so Šele v zadnjih dveh desetletjih nastali izven ravnine $\mathrm{v}$ Sirకih dolinah ob prometnih poteh Goričkega, so si izoblikovali svoja lokalna gravitacijska zaledja, ki so se povezala $z$ obmoxji dnevne migracije na ravnini. Obmoxje dnevne migracije se je tako razßirilo na celotno Prekmurje, vendar pa je na osrednjem Gorixkem in na nekaterih obmejnih obmoxjih razvito $v$ tako skromni obliki, da ni moglo preprexiti depopulacije teh obmoxij.

Novonastali industrijski obrati imajo vecinoma podružniðni značaj obratov iz Murske Sobote, ali pa so njihovi matix̌ni obrati v oddaljenih krajih Slovenije. Razen obrata v Turniš̌u, ki se je razvil v pomembno izvozno podjetje కportne obutve mednarodnega slovesa, pa zaposlujejo ostala podružnična podjetja skoraj izkljuřno le nekvalificirano in polkvalificirano ter $\mathbf{v}$ glavnem le žensko delovno silo $\mathrm{z}$ nizko izobrazbo, ki je $\mathrm{v}$ večini primerov le na ravni dokončane osnovne sole. Zaposlovanje slabo izobraženega in nizko kvalificiranega prebivalstva pa je tudi edini prispevek $\mathrm{k}$ zadržanju prebivalstva $\mathrm{v}$ tem prostoru in edini prispevek $\mathrm{k}$ zbolj§anju prostorskih struktur omenjenih obmoxij griðevnate goriðke pokrajine. Zaradi konfiguracije reliefa in večinoma slabo razvitega lokalnega cestnega omrežja pa ostajajo izven vpliva novejše industrializacije posameznih industrijskih krajev obsežna, zlasti obmejna obmocjja. (Olas, 1990).

Prekmurje je $\mathbf{v}$ zadnjih tridesetih letih $\mathbf{v}$ procesu industrializacije doživljalo na eni strani proces razkroja agrarne strukture prebivalstva, katero na drugi strani $\mathbf{v}$ razlǐni intenzivnosti nadomeša struktura prebivalstva urbane družbe. To se najbolj izrazito kaže $\mathrm{v}$ mehanið̌nem gibanju prebivalstva in staranju le-tega ter v preoblikovapju strukture cistih kmeðkih gospodinjstev s kmeðkim gospodarstvom v strukturo polkmeckih in nekmečkih gospodinjstev s kme`kim gospodarstvom. Značilnost prehoda Prekmurja iz agrarne v neagrarno družbo je, da je velik del gospodinjstev izven Murske Sobote in Lendave še vedno povezanih s kmetijsko obdelavo zemlje, deloma tako, da ostaja eden od zakoncev doma na kmetiji, eden pa je zaposlen $\mathbf{v}$ ostalih panogah gospodarskih de javnosti. $\mathbf{K}$ temu tipu gospodinjstev spadajo tudi tista, kjer je starejła generacija (stara nad 50 let)zaposlena na kmetiji, mlada generacija pa izven kmetijstva (Olas, 1982). 
Na ravninskem obmoxju med Cankovo, Mursko Soboto, Beltinci in Lendavo, kjer sta se industrializacija in urbanizacija podeželja priðeli že kmalu po drugi svetovni vojni, pa je vse veð takih kmeckih gospodinjstev $\mathbf{s}$ kmečkim gospodarstvom, kjer so vsi odrasli zaposleni izven kmetijstva, delo na zemlji pa jim služi le kot dodatni vir dohodka.

Na perifernih in vecinoma obmejnih obmoxjih pa, razen na obmoxju Cankove, Kuzme in Lendave, vse bolj prevladujejo taka gospodinjstva s kmeðkim gospodarstvom, kjer se vsi člani gospodinjstva ukvarjajo s kmetijstvom.

Delež kmečkega prebivalstva je $\mathrm{v}$ razdobju med leti 1961 in 1981 v močnem nazadovanju, saj se je iz dveh tretjin zmanjšl na dobre tri desetine, vendar tudi to nazadovanje ni povsod enako. $\mathrm{V}$ tem procesu zmanjševanja deleža kmeðkega prebivalstva pa obmejna obmoðja zaostajajo, saj imajo še vedno okrog $40 \%$ kmečkega prebivalstva, vendar je to močno ostarelo in izumira, neagrarno prebivalstvo pa ga nadomešca le v zelo skromni obliki (Diagram 2). Povsem drugacno sliko pa imamo v ravninskem svetu, kjer imamo po kmeð̌kih gospodinmjstvih ob ostarelem kmečkem prebivalstvu tudi mlado, nekmeðko prebivalstvo, ki se je šele $\mathbf{v}$ zadnjih treh desetletjih zaposlilo izven kmetijstva, vecinoma na slabo plačanih delovnih mestih $\mathbf{v}$ industriji, katero terja v glavnem nekvalificirano ali pa polkvalificirano delovno silo (Diagram 1). Ker izumiranje kmeckega prebivalstva ne dohiteva rasti aktivnega prebivalstva, zaposlenega $\mathbf{v}$ neagrarnih dejavnostih, sledimo v vseh obmoxjih Prekmurja padanju deleža aktivnega prebivalstva in $\mathbf{v}$ zvezi $\mathrm{s}$ tem tudi hitremu upadanju deleža prebivalstva zaposlenega $\mathrm{v}$ primarnem sektorju gospodarskih dejavnosti, ki je iz treh cetrtin upadel na slabo polovico. Vzporedno s tem pa močno narašca delež zaposlenih v sekundarnem sektorju, ki je iz slabe desetine leta 1961 narastel na tri desetine leta 1981. Z modernizacijo uprave ter razvojem zdravstva in Solstva, se je povecal tudi delež aktivno zaposlenih v terciarnem in kvartarnem sektorju gospodarskih in negospodarskih dejavnosti in sicer iz $12 \%$ leta 1961 na $21 \%$ leta 1981 . Tudi v obmejnih obmoxjih, ki kažejo sicer negativne znake demografskega razvoja, lahko sledimo podobnim, vendar znatno počasnejšim tendencam pri upadanju stevila in deleža aktivnega prebivalstva in premikom prebivalstva zaposlenega $\mathbf{v}$ primarnem sektorju $\mathbf{v}$ sekundarni, terciarni in kvartarni sektor (Klemencič, 1971).

Ker so bili po drugi svetovni vojni vloženi veliki napori v modernizacijo šlstva, kar se kaže $\mathbf{v}$ oblikovanju takozvanih "centralnih" osnovnih sol in v ukinitvi enorazrednih in dvorazrednih osnovnih šol, se je v celotnem Prekmurju med leti 1961 in 1981 zmanjšal tudi delež starejşih od 15 let, ki nimajo nobene solske izobrazbe ali pa le nedokončano osnovno šolo iz dobre polovice na slabo petino. Istođasno se je za $15 \%$ povecal delež prebivalcev z dokoncano osnovno šolo, za $10 \%$ delež prebivalcev $\mathrm{z}$ dokončano poklicno కolo, za $6 \%$ delež prebivalcev s končano srednjo solo ter za $2,5 \%$ delež prebivalcev z dokonCano višjo ali visoko šolo. 


\section{NOTRANJA DIFERENCIACIJA PREKMURJA PO NEKATERIH ELEMENTIH PROSTORSKIH STRUKTUR}

Razvoj celotnega Prekmurja, se posebej pa vpliv industrializacije in $z$ njo v zvezi razvoj uslužnostnih dejavnosti (కolstvo, zdravstvo, prometna in telekomunikacijska infrastruktura) so prekmursko podeželje, ki je bilo po drugi svetovni vojni se enakomerno razvito, v zadnjih tridesetih letih moxno zdiferencirali. Gospodarske in negospodarske dejavnosti nudijo v Prekmurju človeku zelo razlǐ̌ne možnosti za bivanje, oskrbo, izobraževanje in izkorišcanje prostega casa.Te različne možnosti za življenje in delo prebivalstva se poslediěno kažejo $\mathrm{v}$ gibanju Stevila prebivalstva, $v$ gibanju Stevila gospodinjstev in క̌tevila stanovanj, odnosno hiš, $v$ zadnjih treh desetletjih pa tudi $v$ uveljavljanju urbanizacije podeželja. Na celotnem teritoriju Prekmurja je Stevilo prebivalcev zaradi deagrarizacije, ki je povezana $\mathrm{z}$ odmiranjem kmeðkega prebivalstva in zaradi selitvenih tokov, ki so $\mathbf{v}$ prvih desetletjih po drugi svetovni vojni povezani predvsem $\mathrm{z}$ izseljevanjem, narašalo pođasneje kot $\mathrm{v}$ ostalih regijah Republike Slovenije. $\mathbf{V}$ zadnjih treh desetletjih prihaja $\mathbf{v}$ Prekmurju tudi do diferenciranosti na obmocja doseljevanja $\mathrm{z}$ narašanjem కttevila prebivalstva in na območja odseljevanja $\mathrm{z}$ upadanjem క̌tevila prebivalstva. Na obmocjih koncentracije ali doselitve prebivalstva, se కtevilo prebivalstva veca na osnovi doseljevanja in naravne rasti, na obmoxjih odseljevanja pa se število prebivalstva zmanjšje na racun odmiranja ostarelega kmeðkega prebivalstva, ki ga prirodna rast nekmeckega prebivalstva ne more več nadomešati.

Prekmursko podeželje je močno zdiferencirano tudi glede na rast gospodinjstev, saj so tudi tu zelo izrazite meje med podroxji koncentracije in podroxji praznenja. Kot posledica ustvarjanja novih delovnih mest naraša število gospodinjstev na obmoxjih koncentracije in nazaduje na obmoxjih praznenja. Različna intenzivnost uxinkov industrializacije in urbanizacije pa se s številom stanovanj oziroma hiš kaže tudi v zunanji podobi pokrajine.

Tendence demografskega razvoja, ki so izražene $\mathrm{z}$ gibanjem Stevila prebivalstva, tendence gospodarskega razvoja, ki so izražene z gibanjem Stevila gospodinjstev in spremembe v zunanji podobi pokrajine, ki so izražene s spremembami Stevila stanovanj, nam kažejo na tendence regionalne preobrazbe Prekmurja, obenem pa nam omogocajo mikro- in makrogeografsko regionalizacijo Prekmurja na:

- obmoxja razliðne stopnje urbaniziranosti, $v$ kolikor so tendence rasti pozitivne pri vseh treh zgoraj navedenih elementih in

- obmocja deagrarizacije, $v$ kolikor so pri vseh treh elementih prisotne negativne tendence. Različna rast ali upad teh elementov pa kaže na doloceno prehodnost stopnje regionalne preobrazbe posameznih obmoxij Prekmurja.

Obmoxja z narašcanjem stevila prebivalstva, gospodinjstev in števila stanovanj se కe naprej diferencirajo na dve obmoxji in sicer na obmoxje starejše industrializacije in urbanizacije, ki se v obliki posameznih otokov pojavljajo na obmocju Murske Sobote, Beltinec in Lendave in 
kjer vsi trije navedeni elementi naraš̌ajo že od petdesetih let naprej, ko se je prixela industrializacija teh obmoxij. Po letu 1970 so se z nastajanjem novih industrijskih krajev med Mursko Soboto in Ledavo ta obmoxja razsirila in se povezala $\mathrm{v}$ bolj ali manj sklenjeno urbnanizirano obnfočje na celotnem ravninskem svetu. Ta noveǰ̌a urbanizacija je zajela tudi bližnja obmoðja novih krajev $\mathrm{z}$ industrijo na griðevnatem svetu Goričkega. Medtem, ko so se starejša in novejša obmoxja industrializacije in urbanizacije na ravnini sklenila $v$ enotno obmožje, pa so obmoxja novih industrijskih krajev na Gorixkem ostala izolirana v obliki posameznih otokov sredi obmoxij, kjer se javljajo tendence zmanjševanja števila prebivalstva, gospodinjstev in stanovanj. Tudi pri teh procesih lahko loximo dva tipa obmoxij. Tako imamo obmoxja, kjer stevilo prebivalcev, gospodinjstev ter stanovanj konstantno nazaduje $v$ zadnjih treh desetletjih in obmox̌ja, kjer v vseh treh desetletjih konstantno nazaduje le stevilo prebivalstva, medtem, ko Stevilo gospodinjstev ali pa stevilo stanovanj stagnira.

Med tipi obmo $x_{i j}$, ki kažejo tendence $\mathrm{k}$ nazadovanju in tipi obmo $x_{\mathrm{ij}}$, ki kažejo tendence $\mathrm{k}$ rasti Stevila vseh treh elementov pa loximo క̌ prehodna obmoxja, kjer se med posameznimi desetletji obdobja 1961-1981 uveljavljajo pri prebivalstvu tendence stagnacije, pri gospodinjstvih in stanovanjih pa enkrat tendence narašcanja, drugǐ pa tendence stagnacije ali upadanja (Karta 3). Razmerje med teritoriji obmoxij praznenja in obmoxij koncentracije se je v Prekmurju v zadnjih treh desetlet jih moxno izboljsalo $v$ korist obmoxij koncentracije, saj izkazuje pozitivno rast vseh treh elementov (Stevila prebivalstva, gospodinjstev in stanovanj) skoraj polovica celotnega Prekmurja, š pred letom 1971 pa je obsegal teritorij s takimi tendencami le slabo desetino vsega ozemlja, na njem pa je živelo nekaj več kot $24 \%$ vsega prebivalstva Prekmurja (Tabela 2).

Kljub vsem naporom, da bi kraje $\mathrm{z}$ industrijo razsirili tudi na grǐevnat svet Goriðkega, pa ostaja v zadnjem desetlet ju še vedno vec kot tri desetine poselitvenega prostora in $17 \%$ prebivalcev na obmoxjjih, kjer so prisotni vsi znaki depopulacije $\mathrm{z}$ opušcenimi hišami odnosno stanovanji. Tudi kmetijska zemlja ostaja tod zaradi staranja kmečkega prebivalstva obdelana le Se v neposredni okolici vasi (Tabela 3).

Prehodno obmoxje, kjer se še niso uveljavile niti tendence koncentracije, niti tendence praznenja in je prebivalstvo že vključeno $\mathrm{v}$ dnevno migracijo pa obsega dobro petino ozemlja Prekmurja, poseljuje pa ga nekaj vec kot $12 \%$ prekmurskega prebivalstva (Tabela 4 ).

Pri opredelitvi obmoxij v kategorije praznenja in koncentracije prebivalstva se pa pokažejo velike razlike zaradi uðinkov zaprtosti madžarske meje in odprte meje ob jugoslovanskoavstrijski meji. Ob madžarski meji sodi $\mathrm{v}$ obmoðja praznenja s tendencami razkroja kulturne pokrajine kar dobra polovica vsega obmejnega ozemlja, na katerem živi skoraj slaba tretjina vsega obmejnega prebivalstva tega obmoxja. Nasproti temu pa spada ob avstrijski meji v to kategorijo le dobrih $12 \%$ vsega obmejnega ozemlja, na katerem živi približno $9 \%$ obmejnega prebivalstva. 
Tabela 2

Površine, število prebivalcev in gostota prebivalstva na obmoxjih koncentracije prebivalstva.

\begin{tabular}{|c|c|c|c|c|c|}
\hline \multirow{2}{*}{ 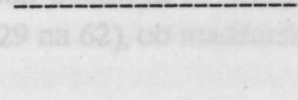 } & & \multicolumn{2}{|c|}{ preb.1987 } & \multirow{2}{*}{$\begin{array}{l}\text { preb./km } \\
1987\end{array}$} \\
\hline & $\mathrm{km}^{2}$ & $\%$ & stev. & $\%$ & \\
\hline $\begin{array}{l}\text { obmoxje ob jugosl.- } \\
\text { avstrijski meji }\end{array}$ & 34,50 & 50,9 & 3.276 & 56,7 & 95,0 \\
\hline obmoxje ob jugosl.- & & 17,3 & 6.203 & & \\
\hline madžarski meji & 31,33 & 17,3 & 0.203 & 31,3 & 196,7 \\
\hline Obmejno obmoxje-skupaj & 66,03 & 26,4 & 9.479 & 53,0 & 143,6 \\
\hline Obxina Murska Sobota & 252,90 & 36,6 & 40.911 & 63,4 & 161,8 \\
\hline Obcina Lendava & 160,01 & 62,5 & 23.987 & 89,4 & 149,9 \\
\hline & 412,91 & 43,6 & 64.898 & 71,0 & 157,2 \\
\hline
\end{tabular}

Tabela 3

PovrŠne, število prebivalcev in gostota prebivalstva na obmoxjïh praznenja in depopulacije.

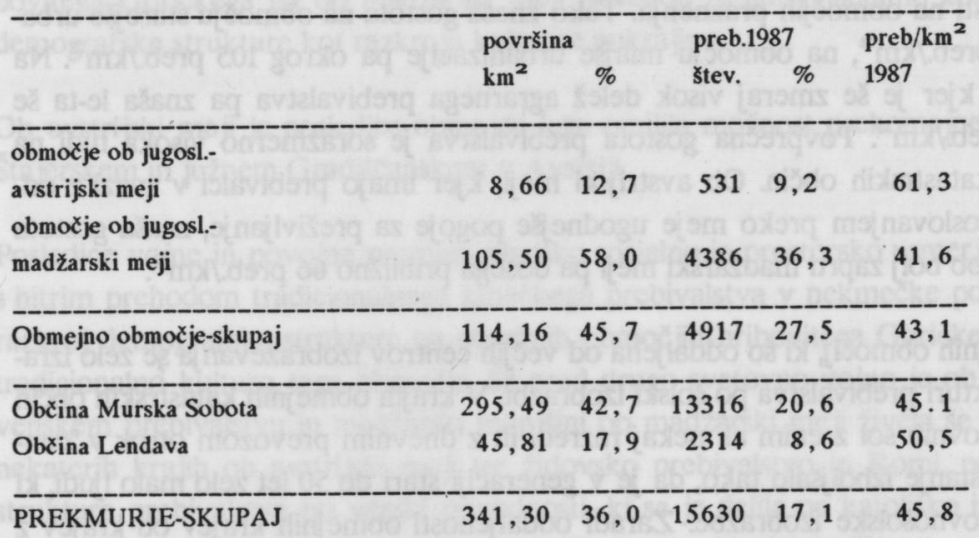


Tabela 4

Površina, število prebivalcev in gostota prebivalstva na prehodnih obmox jị.

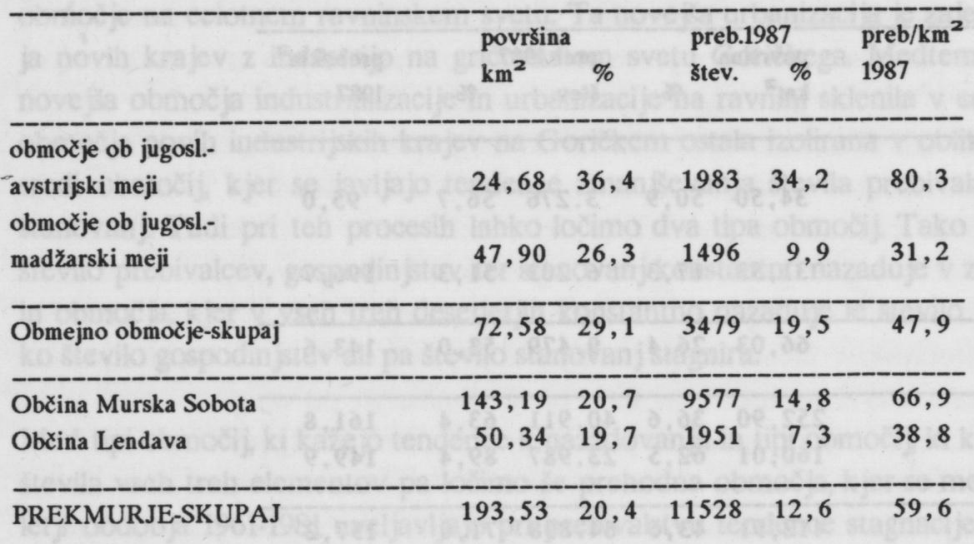

Gostota prebivalstva po teh obmoxjih je glede na nizko stopnjo gospodarske razvitosti sorazmerno visoka, se zlasti na obmoxjih praznenja. Tako znaša gostota na obmoxju starejše urbanizacije okrog 232 preb. $/ \mathrm{km}^{2}$, na obmox̌ju mlajše urbanizacije pa okrog $105 \mathrm{preb} . \mathrm{km}^{2}$. Na obmox̌ju praznenja, kjer je še zmeraj visok delež agrarnega prebivalstva pa znaŠ le-ta ふe zmeraj okrog 50 preb. $/ \mathrm{km}^{2}$. Povprečna gostota prebivalstva je sorazmerno visoka tudi na območju obmejnih katastrskih ob̌̌in. Ob avstrijski meji, kjer imajo prebivalci v zvezi z odprtostjo meje in zaposlovanjem preko meje ugodnejß̌ pogoje za preživljanje, znaša gostota okrog 85 preb./km ${ }^{2}$, ob bolj zaprti madžarski meji pa dosega približno 66 preb./ $\mathrm{km}^{2}$.

Periferna lega obmejnih območij, ki so oddaljena od večjih centrov izobraževanja șe zelo izrazito kaže tudi $v$ strukturi prebivalstva po solski izobrazbi. V krajih obmejnih katastrskih obcin se je $\mathrm{z}$ ukinitvijo osnovnih sol $\mathrm{z}$ enim ali nekaj razredi in $\mathrm{z}$ dnevnim prevozom otrok $\mathrm{v}$ "centralne" osnovne sole stanje izboljæalo tako, da je v generaciji stari do 50 let zelo malo ljudi, ki ne bi imelo vsaj osnovnołolske izobrazbe. Zaradi oddaljenosti obmejnih krajev od krajev z možnostjo srednješolskega izobraževanja in zaradi socialnih razmer pa ta obmoxja znatno zaostajajo predvsem $v$ tistih kategorijah prebivalstva, ki imajo dokončano poklicno, srednjo, višjo ali pa visoko šolo, saj je delež takih precej nižji kot v celotnem Prekmurju ali pa v ostali Sloveniji. Medtem, ko ima v Sloveniji po podatkih iz leta 1981 veट kot osnovnosolsko izobrazbo dokonđano 40,4\% prebivalstva stareǰ̌ega od 15 let, pa znaša ta delež za Prekmurje 26,4\% za podeželje obmejnih obmoxij pa samo $17,6 \%$. 
Negativne tendence socialnega in gospodarskega razvoja in odsotnost rasti mladih nekmeckih gospodinjstev se kaže $\mathbf{v}$ celotnem Prekmurju tudi v tendencah staranja prebivalstva, saj je indeks staranja znašal leta 1961 le 33, leta 1981 pa že 84 . To staranje prebivalstva je na obmejnih obmoxjih za nekaj enot visje, saj se je stopnja staranja poveðala ob avstrijski meji za 33 (iz 29 na 62), ob madžarski meji pa kar za 40 enot (iz 36 na 76).

\section{ZAKLJUČEK}

Prekmurje spada $\mathrm{v}$ obmox̌je nerazvitega, subpanonskega sveta, ki je predstavljalo periferno obmoxje Ogrske že v obdobju do prve svetovne vojne in je kot tako ostalo tudi pozneje v Jugoslaviji in Sloveniji vse do današnjih dni. Ozemlje Prekmurja je bilo tako v preteklosti in je tudi Se danes vstran od vexjih centralnih krajev, ki so se ob koncu XIX. stoletja industrializirali in pridobili pomembne funkcije makroregionalnega pomena. Prekmurje je z zapiranjem politǐnih meja dobilo znađaj perifernega, gospodarsko nerazvitega obmoðja కe posebej po drugi svetovni vojni. To perifernost so $\mathrm{v}$ zadnjih tridesetih letih vsaj do neke mere zmanjšli

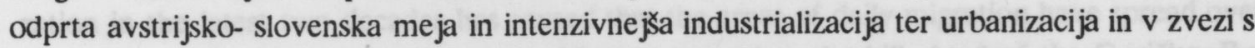
tem hitro prestrukturiranje prostorskih struktur agrarne družbe $\mathrm{v}$ prostorske strukture industrijske družbe. Ta proces je močno zdiferenciral svet ombejnega gorickega hribovja od ravninskega sveta na levem bregu reke Mure. Na Gorickem pa se je podeželje కe poglobljeno diferenciralo kot slabše razvito depopulacijsko obmoxje $\mathrm{z}$ razkrajanjem intaktne demografske strukture agrarnega prebivalstva $\mathrm{v}$ strukturo prebivalstva $\mathrm{v}$ demografskem razkroju. Posledice teh procesov sta predvsem zaprta meja in prometna perifernost. Na obmejnih obmoxjih hribovitega Goričkega pa ob madžarski meji ponekod že lahko sledimo kot posledico razkroja demografske strukture kot razkroju kulturne pokrajine.

Ob avstrijski meji je posledice obmejne lege omilila možnost prekomejnega zaposlovanja na Štajerskem in južnem Gradišcanskem v Avstriji.

Posledice vojne in povojne premalo plansko socialno in prostorsko usmerjene industrializacije $\mathrm{s}$ hitrim prehodom tradicionalnega kmeckega prebivalstva $\mathrm{v}$ nekmecke poklice na ravnini ter razkroj demografske strukture na obsežnih obmoxjih hribovitega Goriækega, so prizadeli tudi tradicionalno kulturo tega obmoxja. Še pred drugo svetovno vojno je ob prevladujoðem slovenskem prebivalstvu in madžarski manjకini ob madžarski meji živela še nemška manjłina $\mathbf{v}$ nekaterih krajih ob avstrijski meji ter židovsko prebivalstvo in Romi, pestra pa je bila tudi struktura prebivalstva po verski pripadnosti, ki se je delila na katoliško in protestantsko slovensko in katolisko in protestantsko madžarsko prebivalstvo. Ker ta pestra kultura ni bila upoštevana, je Prekmurje v veliki meri izgubilo svojo kulturno podobo. Iz obmejnih krajev ob avstrijski meji so bili Nemci nasilno preseljeni, Judje pa uniðeni. Zaradi odseljevanja se je na hribovitem Goričkem močno zmanjふ̌alo število slovenskega in madžarskega prebivalstva, $\mathbf{s}$ tem pa tudi pripadnikov protestantske vere. 
Z uvajanjem koncepta policentrixnega razvoja, s katerim naj bi zagotovili enakomernejßi gospodarski razvoj vseh obmocij Slovenije in s tem tudi celotnega Prekmurja, je bil usmerjen le na ravninski svet Prekmurja. Hribovita obmox ja Gorickega in š posebej obmejna obmoxja, ki so pod močnim udarom depopulacije pa కe naprej ogrožata razseljevanje prebivalstva in razpad kulturne pokrajine, zato je potrebno nujno uveljaviti novi načrt pospeševanja demografsko ogroženih obmocij Slovenije. Ta pa se bo lahko uveljavil le s popolnim odprtjem tako avstrijske, kakor tudi madžarske meje na območju Prekmurja in s skupno zasnovanim načrtom regionalnega in gospodarskega razvoja vseh treh obmejnih obmoxij: Prekmurja v Sloveniji, Štajerske ter Gradišcanske v Avstriji in obmejnih delov županij Vas in Zala na Madžarskem. Tak načrt bo moral poleg pospešenega gospodarskega razvoja upoštevati tudi aspekte kulturnega razvoja $\mathrm{z}$ vidika skupnega obmejnega prostora.

\section{LITERATURA IN VIRI}

1. Olas, L., 1956: Razvoj in problemi sezonskega zaposlovanja prekmurskega prebivalstva, Geografski vestnik XXVII-XXVIII (1955/56), Ljubljana.

2. Olas, L., 1960: Trajne migracije iz Sebeborec (Prekmurje), Geografski vestnik XXXVI (1960), Ljubljana.

3. Olas, L., 1963: Migracije Prekmurcev v stajerski del Pomurja, Geografski vestnik XXXV (1963), Ljubljana (str.15-33).

4. Klemencix, V.,1971: Prostorska diferenciacija Slovenije po selitveni mobilnosti prebivalstva. Geografski zbornik XII (1971), Ljubljana (str. 137-216).

5. Olas, L.,1972: Vpliv migracij na socialni in prostorski razvoj Prekmurja. Geografski simpozij o severovzhodni Sloveniji, Maribor 13.-15.oktobra 1972 (str. 52-63).

6. Olas, L., 1976: Dvolastništvo- dejavnik v razvoju Prekmurja kot obmejne regije. Geografski vestnik XLVIII (1976), Ljubljana (str. 151-155).

7. Olas, L. 1978: Nekateri populacijski problemi Prekmurja kot obmejne regije. II. slovenskoslovaški geografski simpozij, Maribor, 1978 (str. 163-169).

8. Olas,L., 1982: Neki socialnogeografski problemi mełovitih domačinstava u poljoprivredi Pomur ja. Geographica Iugoslavica IV (1982), L jubljana (str. 59-62).

9. Klemencix, V., 1985: Položaj italijanske in madžarske narodnosti in narodnostno mešana obmoxja v Slovenski Istri in Prekmurju v luci socialne geografije. Geographica Slovenica 16, Ljubljana (str. 7-15).

10. Madžari in Slovenci- sodelovanje in sožitje ob jugoslovansko-madžarski meji, Ljubljana, 1987 (614 strani).

11. Klemencic, V., 1987: Državna meja na obmoxju SR Slovenije in obmejna obmox́ja kot nov geografski fenomen. Revija za narodnostna vprašanja, Razprave in gradivo 20 (1987), Ljubljana (str. 57-81). 
12. Suppan, A., 1988: Slowenen und Deutsche in Krein, der Untersteiermark und Slowenien in den Volkszaehlungen von 1880, 1910, 1921 und 1931. Schriftenreihe des oesterreischichen Ost- und Suedosteuropa Institutes, Band XII, Muenchen.

13. Olas, L., 1990: Izseljevanje iz Prekmur ja. Zgodovinski Casopis 44/4, Ljubljana (str. 589-594).

14. Olas, L. 1990: Dislocirani obrati in njihov vpliv na prostorski razvoj Prekmurja. Zbornik razprav Pedagoske fakultete $\mathrm{v}$ Mariboru ( $\mathrm{v}$ tisku). Socialnogeografska regionalizacija in upravna reforma $\mathrm{v}$ Republiki Sloveniji

\section{THE PREKMURJE - AN UNDERDEVELOPED FRONTIER AREA OF SLOVENIA}

The Prekmurje (region on the left side of the Mura river) is an example of a Slovenian region which has opened to regional processes of urban society only in the latest three decades. The reason might be searched for in the relatively late industrialization of the area. The industrialization in the latest two decades has caused that the areas of daily migration have spread over the entire plain on the left side of the Mura river and to the hilly land of the Goricko. But parallel to this process, extensive areas along the Slovenian-Hungarian border, in particular spreading between the town of Lendava on the south and the junction of the Austro-Hungarian-Slovenian triple-frontier on the north, have been left underdeveloped and demographically endangered because of the disintegration of cultural landscape. It is typical for the entire region of the Prekmurje that estates are very fragmented and so industrialization has brought with itself a semi-rural structure of farming husbandries. The traditional, more than a hundred-year-long dependence on seasonal employment abroad has been diminished, but it still remains relatively strong. So the effects of this seasonal employment abroad can be traced in the transformation of the appearance of settlements. In the plain as well as on the marginal hilly land, the old, traditional clay house with thatched roof has been substituted by an urban-villa-like house. Financial means earned through seasonal work are used for modernization of farming techniques and gradual introduction of service activities and production crafts. 
Karta 1:

CVOLASTNIŠKA POSEST PREKMURCEV VAVSTRIJI IN AVSTRIJSKIH DRŽAVLJANOV $\checkmark$ PREKMURJU LETA 1976
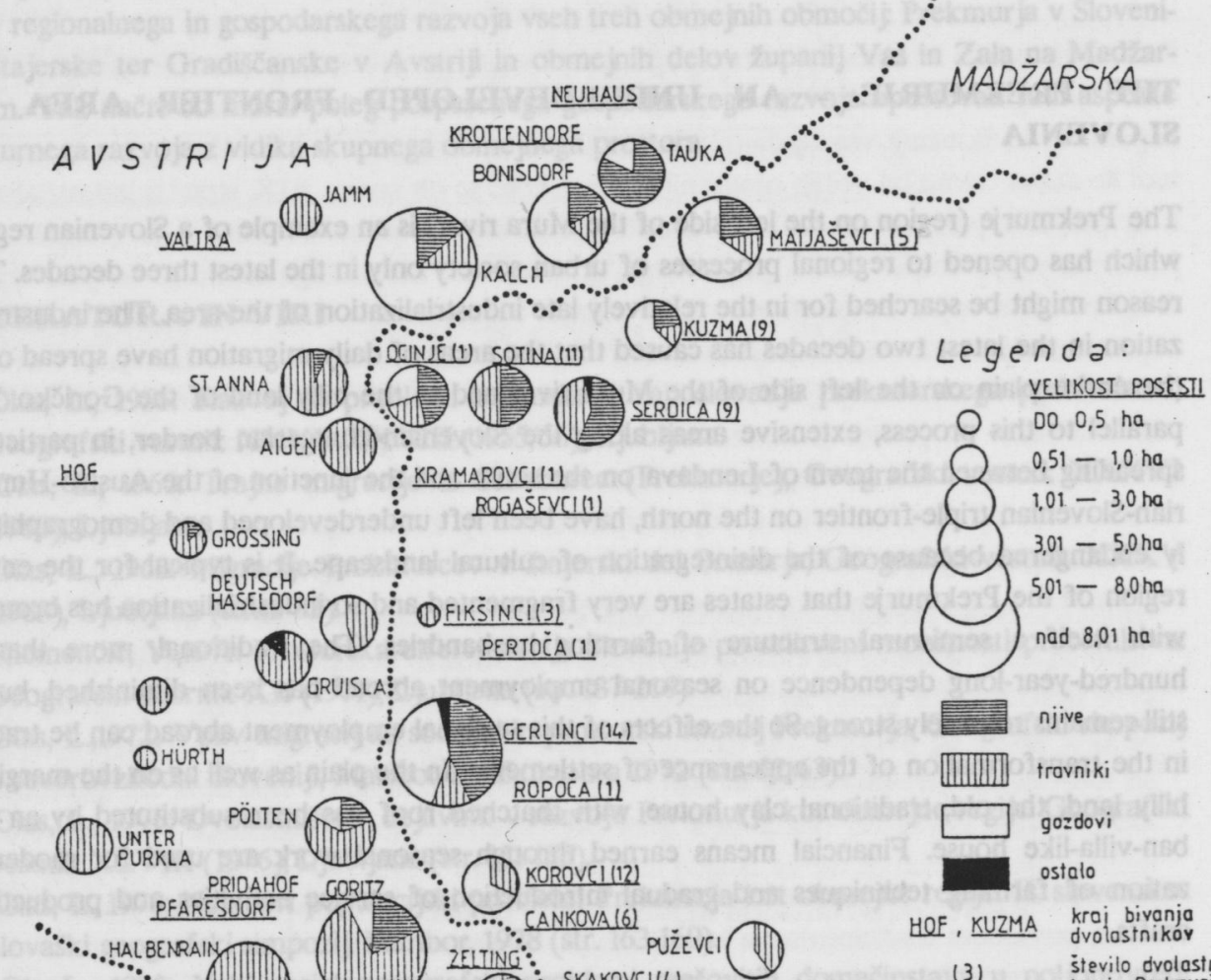

HOF, KUZMA kraj bivanja

(3) stevilo dvolastni: SKAKOVCI(4) kov iz Prekmurja 
Diagram 1:

PRIMER VASI NA OBMOČJU NOVEJŠE KONCENTRACIJE IN URBANIZACIJE NEMCAVCI

starostna struktura prebivalstva leta 1978

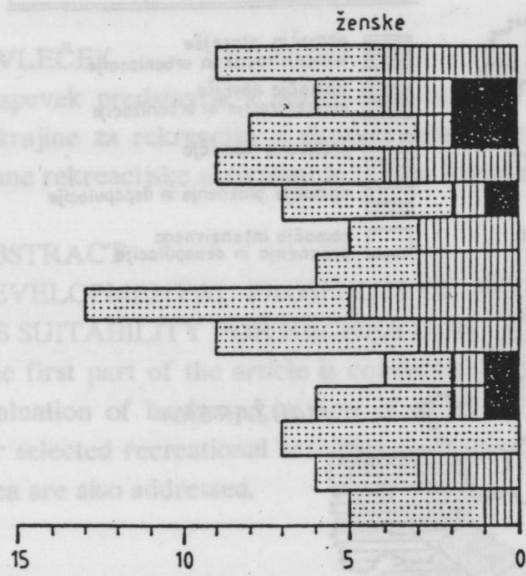

$$
\begin{aligned}
& \text { starost } \\
& 65 \text { in vé } \\
& 60-64 \\
& 55-59 \\
& 50-54 \\
& 45-49 \\
& 40-44 \\
& 35-39 \\
& 30-34 \\
& 25-29 \\
& 20-24 \\
& 15-19 \\
& 10-4 \\
& 5-9 \\
& 0-4
\end{aligned}
$$$$
\text { 1 }
$$

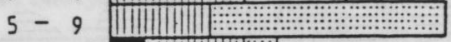

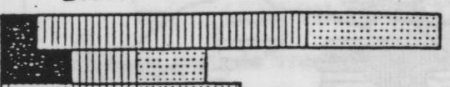

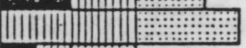

$$
\text { | }
$$

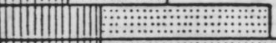

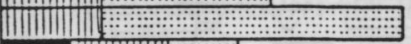

$\therefore$ -

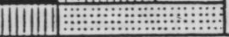

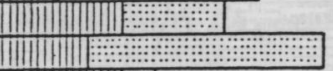

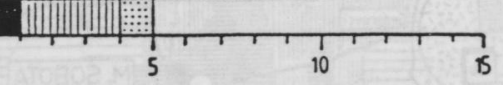

Diagram 2:

PRIMER VASI NA OBMOĆJU INTENZIVNEGA PRAZNENJA IN DEPOPULACIJE PANOVCI

starostna strukfura prebivalstva leta 1978

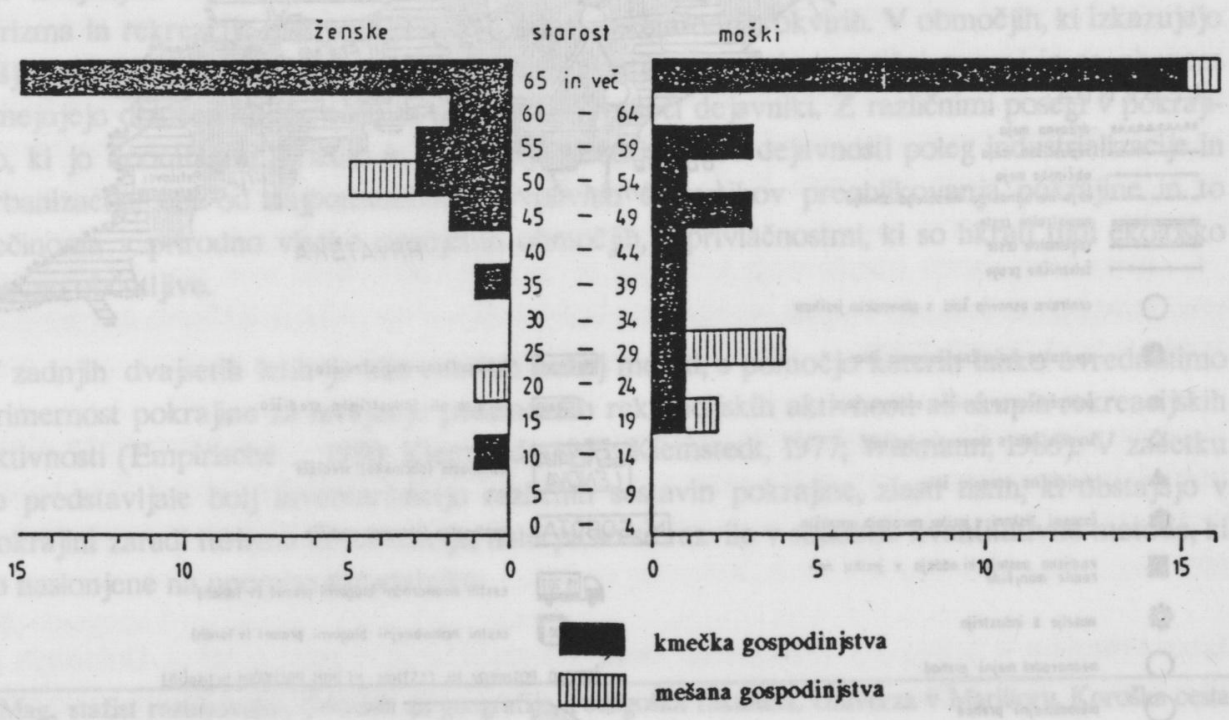


PREKMURJE:

OBMOČJA URBANIZACIJE, TERCIARIZACIJE IN DEPOPULACIJE (prostorske danosti, obmejnost in narodnostna pomešanost)

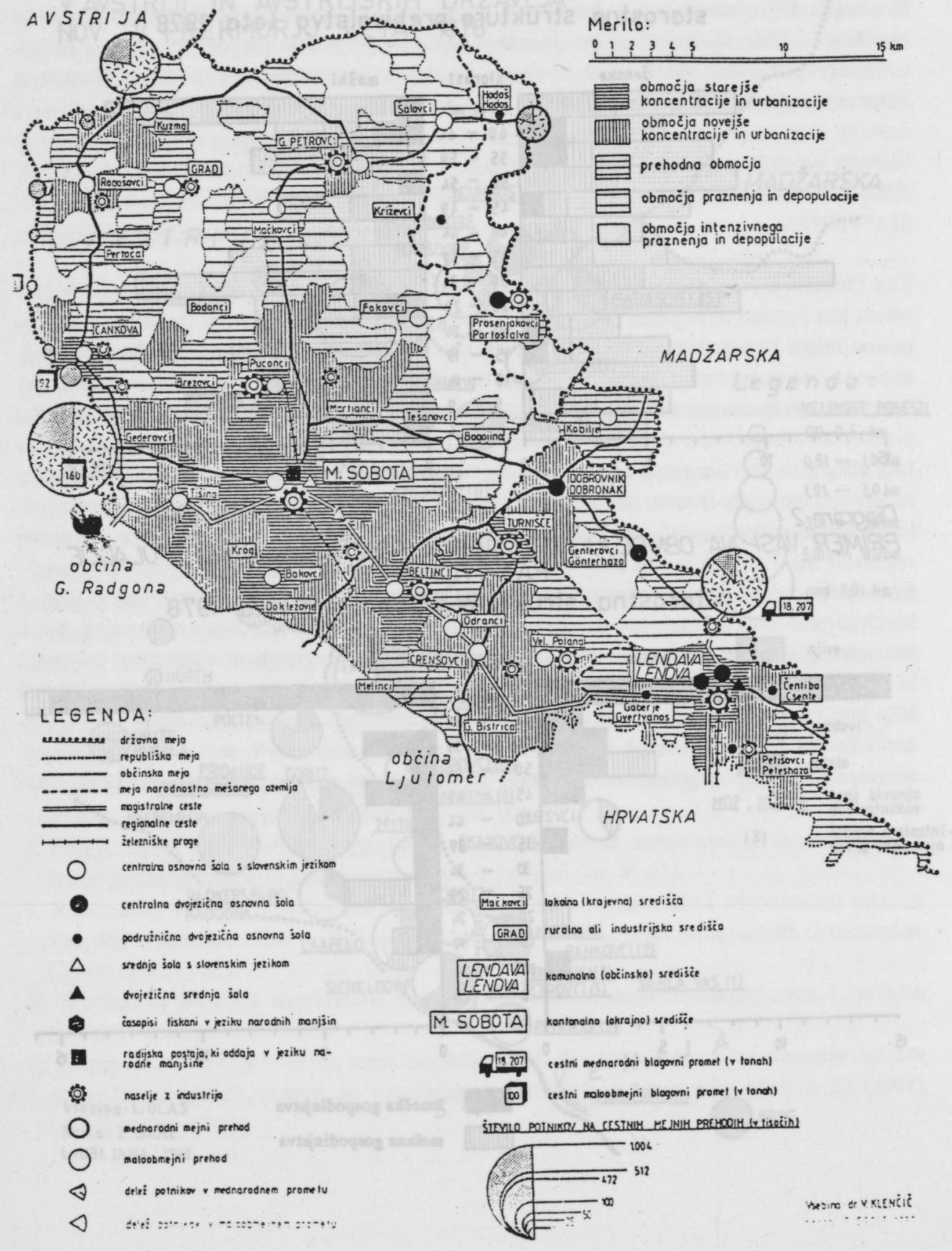

